\title{
PENURUNAN KADAR GLUKOSA DARAH SEWAKTU MELALUI TERAPI REIKI PADA PASIEN DIABETES MELITUS TIPE 2
}

\author{
Ester Inung Sylvia ${ }^{12^{*}}$, Krisna Yetti ${ }^{3}$, Rr.Tutik Sri Hariyati ${ }^{3}$ \\ 1. Poltekkes Kemenkes Palangkaraya, Palangkaraya 75123, Indonesia \\ 2. Program Studi Magister Fakultas Ilmu Keperawatan Universitas Indonesia, Depok 16424, Indonesia \\ 3. Fakultas Ilmu Keperawatan Universitas Indonesia, Depok 16424, Indonesia \\ *Email: esterinungs@yahoo.co.id
}

\begin{abstract}
Abstrak
Reiki merupakan terapi komplementer untuk menurunkan kadar glukosa darah. Terapi ini menggunakan energi alami yang disalurkan pada tubuh pasien dengan tujuan menyelaraskan energi yang tidak seimbang dalam tubuhnya. Penelitian untuk mengetahui pengaruh Reiki terhadap penurunan glukosa darah dan mengidentifikasi apakah faktor stres dan berat badan (obesitas) berperan dalam penurunan KGD pasien Diabetes Melitus tipe 2 dilakukan di Klub Diabetes sebuah RS di Jakarta. Desain penelitian pre-eksperimental dengan pendekatan one-group pretest-posttest design. Sejumlah 18 sampel dipilih dengan teknik purposive sampling. Terapi dilakukan selama tiga puluh hari dengan dua metode, secara langsung dan jarak jauh. Hasil penelitian menunjukkan perbedaan bermakna antara glukosa darah sebelum dan setelah intervensi Reiki $(p=0,000 ; \alpha=0,05)$. Penelitian ini menyarankan penggunaan Reiki dalam asuhan keperawatan.
\end{abstract}

Kata Kunci: diabetes melitus tipe 2, kadar glukosa darah, Reiki, terapi komplementer

Abstract

Reiki is one of the complementary therapies that are used to decrease blood glucose level. The therapy transfers natural energy into the patient's body to synchronize the energy imbalance in the body. The research to examine the effect of Reiki and the role of the stress and weight factor to decrease blood glucose level of DM type 2 patients was held in a hospital-based diabetic club in Jakarta. The design of this study was pre-experimental with the one-group pretest-posttest design. Eighteen patients were selected with the purposive sampling technique. Reiki therapy was performed in 30 days using two methods: direct and distant healing method. The result revealed that there was a significant difference in random blood glucose level before and after the Reiki intervention $(p=0.000 ; \alpha=0.05)$. It is recommended to incorporate the Reiki therapy in nursing care.

Keywords: type 2 Diabetes Mellitus, blood glucose level, Reiki, complementary therapy

\section{Pendahuluan}

Diabetes Melitus (DM) adalah salah satu penyakit kronis yang memerlukan penatalaksanaan jangka panjang. DM ditandai dengan hiperglikemia yang dapat mengakibatkan gangguan organ tubuh seperti mata, jantung, dan ginjal. Penatalaksanaan DM dilakukan melalui Empat Pilar Pengelolaan DM, yaitu perencanaan makan, latihan jasmani, edukasi. dan obat berkhasiat hipoglikemik. Di samping terapi medis, saat ini telah berkembang terapi komplementer untuk membantu mengatasi permasalahan kesehatan pasien.

Terapi komplementer adalah terapi yang sifatnya melengkapi terapi medis dan telah terbukti manfaatnya
(Conn, Hollister, \& Arnold, 2001). Salah satu terapi komplementer yang diklasifikasikan oleh National Center of Com-plementary and Alternative medicine (NCCAM) sebagai terapi "energy medicine" adalah Reiki. Te-rapi Reiki menggunakan energi vital sebagai pe-nyembuhan (McKenzie, 2006; Soegoro, 2002). Pada pasien DM, energi akan disalurkan oleh tangan prak-tisi Reiki melalui cakra (pintu gerbang masuk dan keluarnya energi) mahkota, solar pleksus, dan seks. Cakra mahkota berada di kepala (ubun-ubun), solar pleksus di area ulu hati, dan cakra seks di sekitar da-sar punggung/ perineum.

Penyembuhan terjadi melalui suatu proses dimana energi menstimulasi sel-sel dan jaringan yang rusak untuk kembali pada fungsinya yang normal (Goldberg, 
1997, dalam Sjahdeini, 2005) dan diharapkan kadar glukosa darah menjadi normal termasuk menurunkan resistensi insulin pada pasien DM yang mengalami obesitas.

Relaksasi dan meditasi dalam terapi Reiki juga menyebabkan sistem saraf simpatis diinhibisi sehingga menghambat sekresi norepineprin (Benson \& Proctor, 2000). Inhibisi norepineprin menyebabkan frekuensi jantung, pernafasan, dan glukosa darah menurun. Selain itu hipofisis anterior juga diinhibisi sehingga ACTH yang mensekresi hormon stres seperti kortisol menurun sehingga proses glukoneogenesis, serta katabolisme protein dan lemak yang berperan dalam peningkatan glukosa darah juga menurun (Guyton, 1996; Smeltzer \& Bare, 2002).

Reiki berkembang pesat di luar negeri. Reiki mulai diminati oleh perawat, dokter, dan ahli rehabilitasi, khususnya di Amerika. Mereka mengkombinasikan Reiki dengan terapi medis dalam menyembuhkan pasien (Vitale, 2007). Tercatat hingga akhir 2002 kurang lebih 50 rumah sakit dan klinik-klinik di Amerika Serikat telah menawarkan Reiki kepada pasien-pasiennya (DiNucci, 2005).

Reiki baru dikenal di Indonesia pada tahun 1990-an (Ishaq, 2002). Sejak saat itu klinik-klinik Reiki mulai dibuka untuk melayani masyarakat yang mengalami permasalahan kesehatan. Namun, tidak ada laporan bahwa rumah sakit telah menyediakan fasilitas terapi ini sebagai terapi pelengkap dari terapi medis. Salah satu rumah sakit rujukan di Jakarta memberikan pelayanan pada pasien DM melalui empat pilar tatalaksana DM tersebut. Namun, belum ada laporan bahwa terapi Reiki digunakan untuk melengkapi penatalaksanaan empat pilar itu. Tujuan penelitan ini adalah untuk menjelaskan pengaruh Reiki terhadap penurunan kadar glukosa darah (KGD) pasien DM tipe 2 dan mengidentifikasi apakah faktor stres dan berat badan (obesitas) berperan dalam penurunan KGD pasien.

\section{Metode}

Desain penelitian ini menggunakan metode praeksperimen dengan pendekatan one-group pretestposttest design (before and after). Sampel pada penelitian ini diambil dengan metode purposive sampling dengan kriteria: pasien DM tipe 2 yang taat mengikuti program 4 pilar penatalaksanaan DM, perempuan, usia 45-65 tahun, mepunyai riwayat penyakit keluarga DM, Kadar Glukosa Darah Sewaktu (KGDS) relatif stabil dalam dua bulan terakhir, pasien yakin bahwa Reiki dapat membantu menurunkan KGDS, bersedia diberikan intervensi Reiki selama 30 hari selain dengan terapi standar dari rumah sakit. Jumlah sampel penelitian sebanyak 18 responden.

Instrumen yang digunakan glukometer, modifikasi skala stres Holmes \& Rahe, alat pengukur berat dan tinggi badan, serta lembar isian. Glukometer dapat mengukur kadar glukosa darah dalam rentang 10-600 mg/dL.

Tabel 1. Karakteristik Responden Klub Diabetes

\begin{tabular}{llc}
\hline \multicolumn{1}{c}{ Karakteristik Responden } & $\mathbf{n}$ & $\mathbf{\%}$ \\
\hline Obat Hipoglikemik Oral yang digunakan & & \\
a. Pemicu sekresi insulin & 4 & 22,2 \\
b. Penambah sensitivitas insulin & 8 & 44,4 \\
c. Kombinasi & 6 & 33,3 \\
Berat Badan & & \\
a. Obesitas & 9 & 50,0 \\
b. Tidak Obesitas & 9 & 50,0 \\
Tingkatan Stres & & 33,3 \\
a. Stres Ringan & 6 & 38,9 \\
b. Stres Sedang & 7 & 27,8 \\
c. Stres Berat & 5 & \\
\hline
\end{tabular}


Kuesioner pada skala stress Holmes \& Rahe menilai empat puluh tiga (43) peristiwa hidup yang telah diteliti sebagai peristiwa yang paling umum dan sering menyebabkan stres. Berat badan dan tinggi badan diukur menggunakan alat tetap yang telah disediakan di rumah sakit. Sedangkan lembar isian digunakan sebagai pedoman wawancara dan observasi.

Pelaksanaan terapi Reiki 20-30 menit tiap hari selama 30 hari. Terapi Reiki dilakukan melalui dua metode, yaitu penyembuhan secara langsung dan jarak jauh (distant healing). Penyembuhan secara langsung dilaksanakan setelah responden melaksanakan senam di Klub Diabetes Instalasi Rehabilitasi Medis di RS lokasi penelitian di wilayah Jakarta. Perhiasan responden dari bahan kulit dan logam sementara dilepas, duduk rileks, tangan diletakkan di pangkuan, dan mata dipejamkan. Saat responden masuk tahap meditasi, peneliti melakukan penyelarasan energi tubuh menggunakan tangan yang diletakkan $5 \mathrm{~cm}$ di atas tiga cakra utama. Pe- nyembuhan jarak jauh dilaksanakan dengan waktu yang telah disepakati setiap hari selain Selasa dan Kamis.

Tata cara sama dengan terapi langsung hanya posisi responden dan peneliti di rumah masing-masing. Transfer energi dibantu oleh dua orang master Reiki dari salah satu Klinik Reiki di Jakarta. Pemeriksaan kadar glukosa darah sewaktu dilakukan sebelum dan setelah tiga puluh (30) mengikuti terapi Reiki. Jenis, jumlah makanan, dan waktu makan baik sebelum dan sesudah terapi harus sama sehingga dilakukan pencatatan diawal terapi dan mengingatkan responden melalui via telepon sehari sebelum pemeriksaan glukosa darah ke dua. Hal ini dilakukan untuk meminimalkan bias dari hasil pemeriksaan KGDS I dengan II.

Analisis data pada penelitian ini diolah dengan program statistik. Analisis meliputi analisis univariat dari frekuensi, nilai tengah, dan penyebaran karakteristik responden, variabel bebas, terikat, dan perancu.

Tabel 2. Kadar Glukosa Darah Sewaktu I dan II Klub Diabetes

\begin{tabular}{lcccc}
\hline \multicolumn{1}{c}{ Variabel } & Mean & SD & Min-Max & 95\% CI \\
\hline K GDS I & 224,89 & 48,16 & $138-293$ & $200,89-248,84$ \\
KGDS II & 177,17 & 42,13 & $112-240$ & $156,22-198,12$ \\
\hline
\end{tabular}

Analisis selanjutnya adalah mendeskripsikan perubahan rerata KGDS sebelum dan setelah terapi Reiki, kemudian dihubungkan dengan faktor stres dan berat badan.

\section{Hasil}

Penelitian dilaksanakan selama enam minggu. Penelitian ini dimulai minggu ketiga Mei sampai minggu keempat Juni 2008 di Klub Diabetes di sebuah rumah sakit di Jakarta. Hasil penelitian adalah sebagai berikut:

\section{Karakteristik Responden}

Distribusi karakteristik responden menunjukkan bahwa jenis $\mathrm{OHO}$ yang digunakan oleh responden ham- pir merata, paling banyak responden menggunakan OHO jenis penambah sensitivitas insulin, yaitu 8 responden (44,4\%). Distribusi status berat badan antara responden yang dikategorikan obesitas dengan yang tidak obesitas sama besar, yaitu 9 responden (50\%), sedangkan tingkatan stres responden hampir merata untuk masing-masing tingkatan stres. Paling banyak responden mengalami stres sedang yaitu 7 responden $(38,9 \%)$ (lihat pada tabel 1$)$.

Pada tabel 2 memperlihatkan bahwa rerata KGDS pada pemeriksaan I adalah $224,89 \mathrm{mg} / \mathrm{dL}$ dengan KGDS I terendah $138 \mathrm{mg} / \mathrm{dL}$ dan tertinggi $293 \mathrm{mg} /$ dL. Sedangkan rerata KGDS pada pemeriksaan II adalah $177,17 \mathrm{mg} / \mathrm{dL}$ dengan KGDS II terendah $112 \mathrm{mg} / \mathrm{dL}$ dan tertinggi $240 \mathrm{mg} / \mathrm{dL}$. 


\section{Perbedaan Rerata KGDS Sebelum dan Setelah Diberikan Terapi Reiki selama 30 Hari}

Pada grafik 1 menunjukkan bahwa responden tetap menjalani terapi standar dari rumah sakit dan dikombinasikan dengan terapi Reiki. Hasil penelitian menunjukkan bahwa adanya penurunan KGDS responden setelah diberikan terapi Reiki 30 hari, sekitar $47,72 \mathrm{mg} / \mathrm{dL}(\mathrm{p}=0,000 ; \alpha=0,05)$. Namun bila dilihat secara individu, penurunan rerata KGDS responden berkisar antara 5-121 mg/dL (lihat pada grafik 2).

\section{Pengaruh Stres pada Penurunan Rerata KGDS}

Pada grafik 3 menunjukkan bahwa ada penurunan rerata KGDS responden. Penurunan KGDS yang terbesar terjadi pada responden dengan stres ringan (penurunan 71,17 mg/dL). Hasil analisis lanjut menunjukkan bahwa tidak ada perbedaan bermakna penurunan rerata KGDS responden baik yang stres ringan, sedang, maupun berat sebelum dan sesudah terapi $(p=0,273 ; p=0,874 ; \alpha=0,05)$.

\section{Pengaruh Berat Badan terhadap Perubahan KGDS}

Pada grafik 4 memperlihatkan bahwa penurunan rerata KGDS terjadi baik pada responden yang obe- sitas maupun yang tidak obesitas. Penurunan rerata KGDS pada responden obesitas dari 219,78 mg/dL menjadi $171,56 \mathrm{mg} / \mathrm{dL}$. Sedangkan, rerata penurunan KGDS responden yang tidak obesitas dari 230,00 mg/dL menjadi 182,78 mg/dL. Selisih rerata penurunan KGDS pada responden yang obesitas maupun tidak obesitas tidak jauh berbeda, yaitu 48 , $22 \mathrm{mg} / \mathrm{dL}$ dan 47,22 mg/dL $(\mathrm{p}=0,666 ; \mathrm{p}=0,588$; $\alpha=0,05)$.

\section{Pembahasan}

Kadar glukosa darah pasien DM sangat dipengaruhi banyak faktor, antara lain stres dan obesitas. Stres pada pasien DM dapat menyebabkan peningkatan glukosa darah (Smeltzer \& Bare, 2002). Pada kondisi stres, individu akan mengeluarkan hormonhormon stres yang mempengaruhi peningkatan glukosa darah. ACTH akan menstimulasi pituitari anterior untuk memproduksi glukokortikoid, terutama kortisol. Peningkatan kortisol menyebabkan peningkatan kadar glukosa darah (Guyton, 1996; Smeltzer \& Bare, 2002). Selain itu kortisol juga dapat menginhibisi ambilan glukosa oleh sel tubuh (Individual Wellbeing Diagnostic Laboratories, 2008).

Grafik 1. Perbedaan Rerata KGDS Responden Sebelum dan Sesudah Terapi Reiki selama 30 Hari

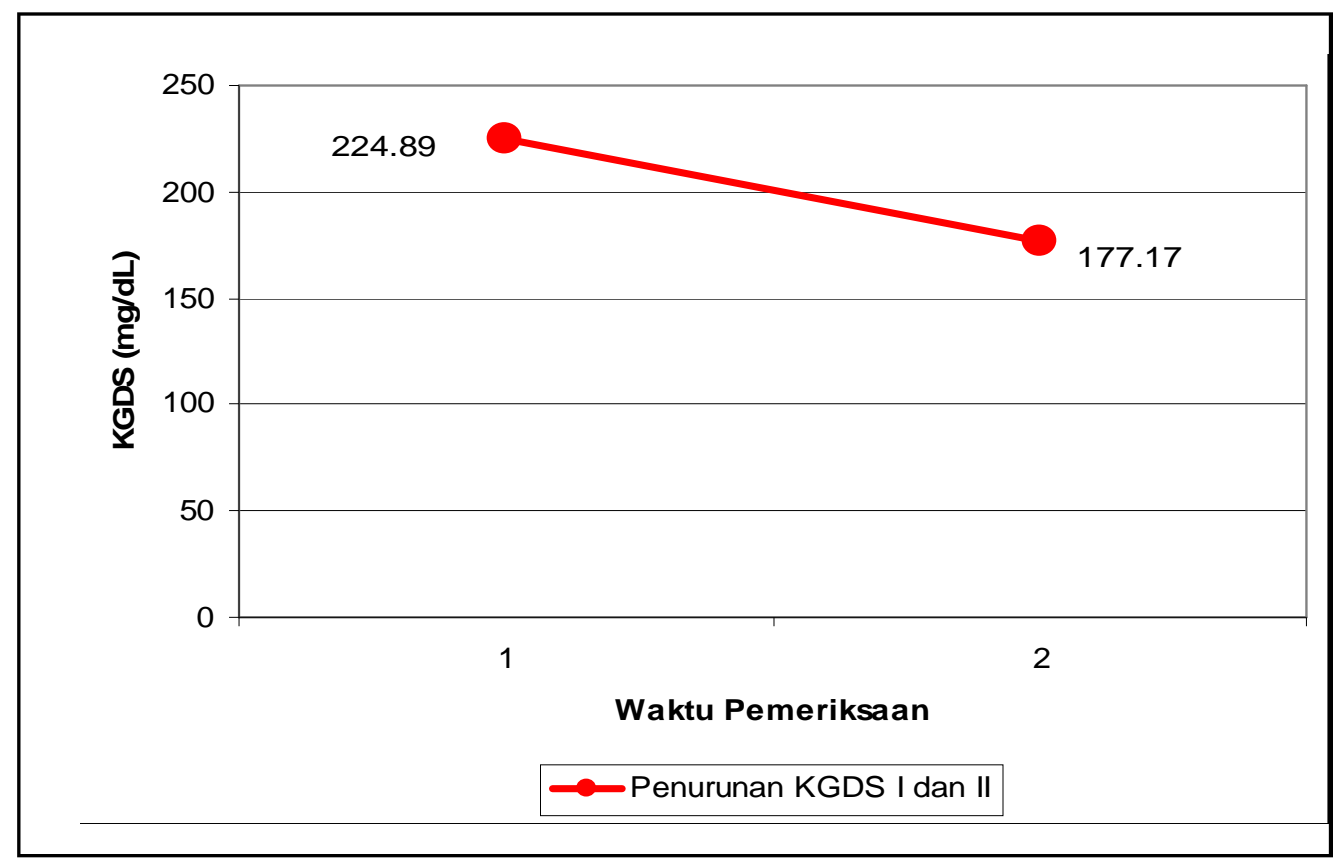


Salah satu terapi yang dapat membantu menurunkan KGDS pasien DM adalah terapi Reiki melalui relaksasi dan meditasi. Pada kondisi rileks terjadi perubahan impuls saraf pada jalur aferen ke otak dimana aktivasi menjadi inhibisi. Perubahan impuls saraf ini menyebabkan perasaan tenang baik secara fisik maupun mental seperti berkurangnya denyut jantung, menurunnya kecepatan metabolisme tubuh dalam hal ini mencegah peningkatan glukosa darah (Guyton, 1996; Smeltzer \& Bare, 2002).

Hipofisis anterior juga diinhibisi sehingga ACTH yang mensekresi kortisol menurun, kemudian glukoneogenesis, katabolisme protein, dan lemak yang berperan dalam peningkatan glukosa darah juga menurun (Guyton, 1996). Goldberg (1997), menerangkan bahwa pada saat rileks energi Reiki lebih dahsyat mencari sendiri sumber penyakit dan menstimulasi sel-sel dan jaringan yang rusak untuk kembali pada fungsinya yang normal (Sjahdeini, 2005).

Hasil penelitian menunjukkan bahwa ada penurunan KGDS responden setelah diberikan terapi
Reiki 30 hari, sekitar 47,72 mg/dL ( $p=0,000 ; \alpha=$ $0,05)$. Bila dilihat secara individu penurunan rerata KGDS responden berkisar antara 5 sampai 121 mg/dL (grafik 2). Namun, keadaan ini berbeda pada 2 (dua) responden nomor 11 dan 17. Pada pemeriksaan KGDS II, kadar glukosa darah dua responden meningkat 16 sampai $20 \mathrm{mg} / \mathrm{dL}$. Hal ini diakuinya sebagai bentuk stres karena mempunyai masalah keluarga dan saat mengikuti suatu acara, responden tidak memperhatikan diit yang dianjurkan edukator.

Pendapat Smeltzer dan Bare (2002) dan Guyton (1996) bahwa pasien DM yang mengalami stres dapat mengubah pola makan, latihan, dan kepatuhan penggunaan obat. Hal ini sesuai dengan hasil penelitian, yaitu kondisi ini yang menyebabkan glukosa darah pasien meningkat.

Penurunan KGDS terbesar terjadi pada responden dengan stres ringan, yaitu 71,17 mg/dL (grafik 3). Hasil penelitian menunjukkan bahwa tidak ada perbedaan bermakna penurunan rerata KGDS responden baik yang stres ringan, sedang, maupun berat,

Grafik 2. Perubahan KGDS Masing-Masing Responden Sebelum dan Sesudah Terapi Reiki selama 30 Hari

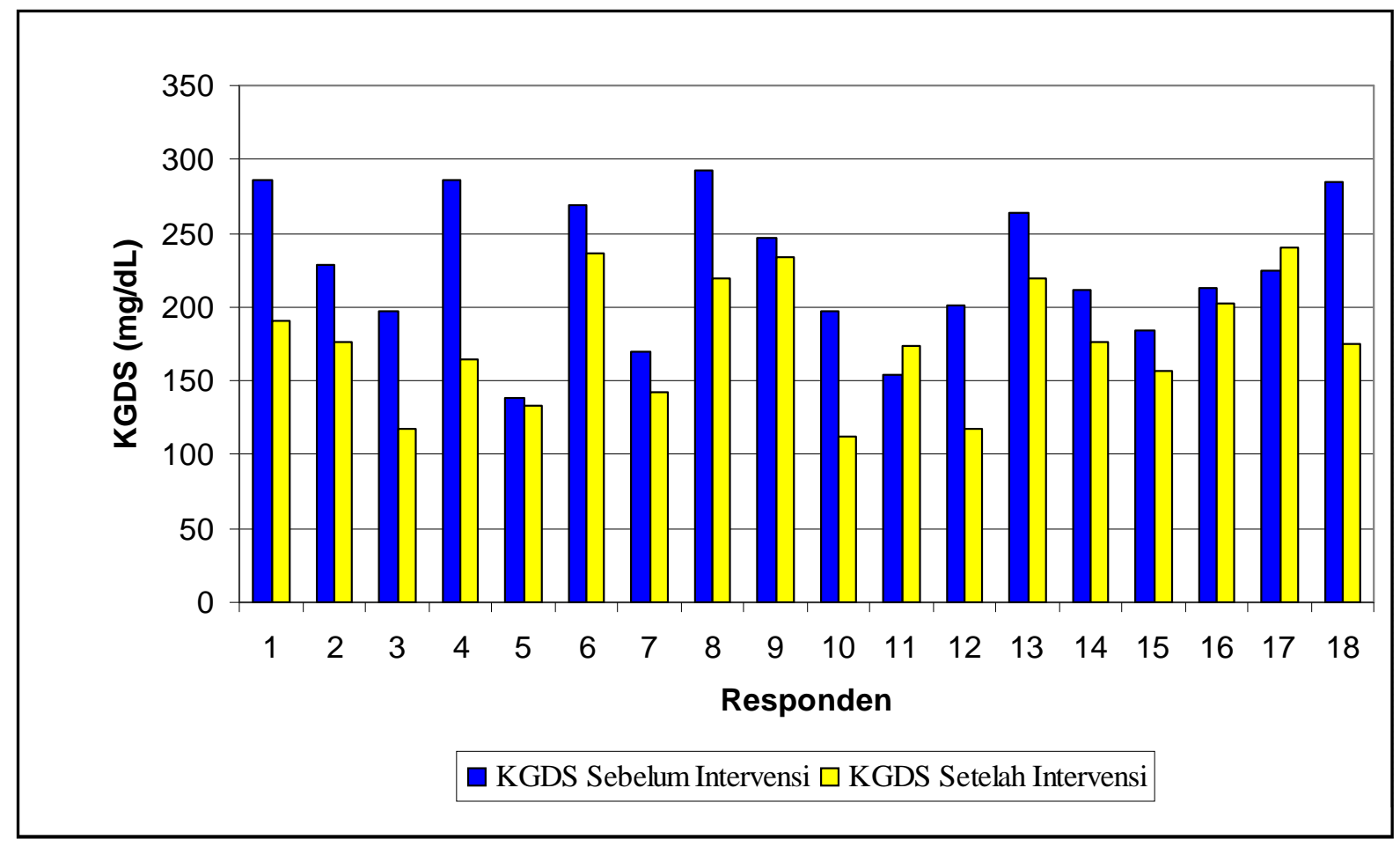


sebelum dan sesudah terapi $(\mathrm{p}=0,273 ; 0,874 ; \alpha=$ $0,05)$. Hal ini diperkirakan karena skala stres yang digunakan tidak tepat, adaptasi responden berbeda-beda, dan sampel yang sedikit.

Skala stres Holmes dan Rahe memberikan skor pada setiap butir stresor, tetapi tidak memperlihatkan rentang penerimaan yang memungkinkan individu untuk menilai sendiri seberapa besar respon individu tersebut terhadap stres dengan stresor yang sama. Kozier, Erb, Blais, dan Wilkinson (1995) menjelaskan bahwa penerimaan dan respon terhadap stres seseorang bersifat individual.

Pernyataan tersebut di atas tergantung dari pengalaman, proses belajar, pertumbuhan, perkembangan, status kesehatan, dan koping. Disamping itu, sensasi energi Reiki yang dirasakan responden berbedabeda. Sebagian besar responden merasakan ada aliran yang hangat mengalir dari kepala hingga kaki, tangan dan kaki kesemutan, gemetar, ada beban turun dan lepas dari tubuh, dan organ tubuh tertentu seperti ditusuk-tusuk jarum kecil. Hal ini sesuai dengan pernyataan Moore (2007) bahwa sensasi yang umumnya dirasakan adalah perasaan panas, dingin, berdenyut, gemetar, terasa berat, atau sama sekali tidak merasakan sensasi.
Reaksi responden selama terapi juga berbeda-beda. Ada yang memperlihatkan suasana hati yang tenang, adapula yang menangis. Hal ini sesuai dengan yang dinyatakan oleh Sjahdeini (2005) bahwa selama proses terapi terkadang seseorang menunjukkan berbagai reaksi, misalnya tertawa terbahakbahak dan menangis tersedu-sedu. Hal ini terjadi karena seseorang berusaha mengeluarkan emosi yang terpendam di alam bawah sadarnya.

Selain faktor stres yang dapat meningkatkan kadar glukosa darah, obesitas juga demikian. Obesitas menyebabkan respon sel beta pankreas terhadap peningkatan glukosa darah menjadi berkurang. Reseptor insulin pada target sel di seluruh tubuh diabetes kurang sensitif dan jumlahnya berkurang sehingga insulin dalam darah tidak dapat dimanfaatkan (Soegondo, 2007).

Hasil penelitian memperlihatkan penurunan rerata KGDS terjadi baik pada responden yang obesitas maupun yang tidak obesitas. Selisih rerata penurunan KGDS pada responden yang obesitas maupun tidak obesitas tidak jauh berbeda, yaitu 48,22 mg/dL dan $47,22 \mathrm{mg} / \mathrm{dL}(\mathrm{p}=0,666$ dan $\mathrm{p}=0,588)$. Pada penelitian ini variabel berat badan (obesitas) tidak ada kontribusi dalam penurunan KGDS.

Grafik 3. Rerata Penurunan KGDS Menurut Tingkat Stres

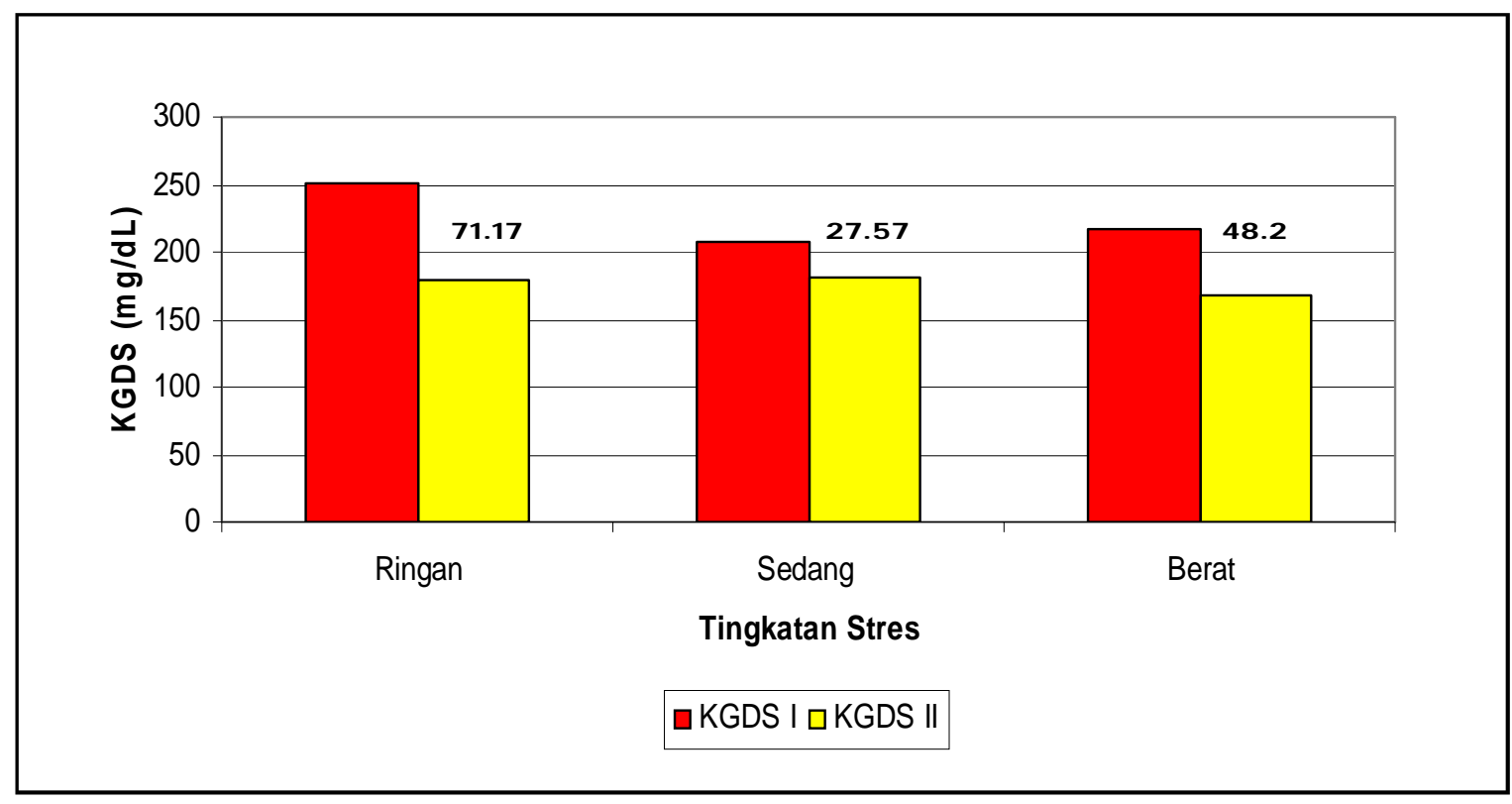


Hasil ini dapat disebabkan karena jumlah sampel yang sedikit, sehingga menghasilkan nilai yang tidak signifikan. Hal ini didukung dari salah satu studi komparatif dalam pemberian terapi yang sama. Studi A dengan jumlah sampel banyak dan studi B dengan sampel sedikit menghasilkan nilai $\mathrm{p}$ yang berbeda jauh, yaitu $\mathrm{p}$ studi $\mathrm{A}=0,005$ dan studi $\mathrm{B}=0,14$ (Elwood, 2007).

\section{Kesimpulan}

Terapi Reiki yang dilakukan selama 30 hari pada penelitian ini terbukti dapat menurunkan KGDS pasien Diabetes Melitus tipe 2 secara bermakna. penurunan KGDS ini tidak dipengaruhi oleh faktor stres dan obesitas. Terapi Reiki terbukti dapat menurunkan kadar glukosa darah pasien Diabetes Melitus tipe 2. Terapi ini merupakan terapi pelengkap yang dapat digunakan di tatanan pelayanan kesehatan terutama di bagian keperawatan medikal bedah sebagai salah satu standar operasional prosedur pada pasien Diabetes Melitus tipe 2.

Penelitian selanjutnya sebaiknya dilakukan pada sampel yang lebih besar dengan desain penelitian eksperimen paralel,yaitu ada kelompok eksperimen dan kontrol. Penelitian lanjutan yang dapat dilakukan diantaranya mengenai pengaruh terapi Reiki pada perubahan fisiologis pasien DM tipe 2 dalam penurunan kadar glukosa darah, pengaruh terapi Reiki terhadap penurunan kadar glukosa darah pasien Diabetes Melitus Tipe 2 yang mendapatkan pengobatan insulin, serta pengaruh faktor stres terhadap penurunan kadar glukosa darah dengan skala stres yang lain (IDA, $\mathrm{HH}, \mathrm{TN}$ ).

\section{Referensi}

Benson, H., \& Proctor, W. (2000). Dasar-dasar respon relaksasi: Bagaimana menggabungkan respons relaksasi dengan keyakinan pribadi anda. (Alih bahasa oleh Nurhasan). Bandung: Kaifa.

Conn, D.L., Hollister, R., \& Arnold, W.J. (2001). Alternative care for artrhitis and related musculoskeletal disease, dalam Ruddy, S., Harris, E.D., \& Sledge, C.. Kelley's textbook of rheumatology (6th Ed.). Philadelphia: WB Saunders.

Crisp, J. (2001). Potter and Perry's fundamentals of nursing. Philadelphia: Harcourt Publisher International.

Grafik 4. Perubahan Rerata Penurunan KGDS Responden menurut Status Obesitas

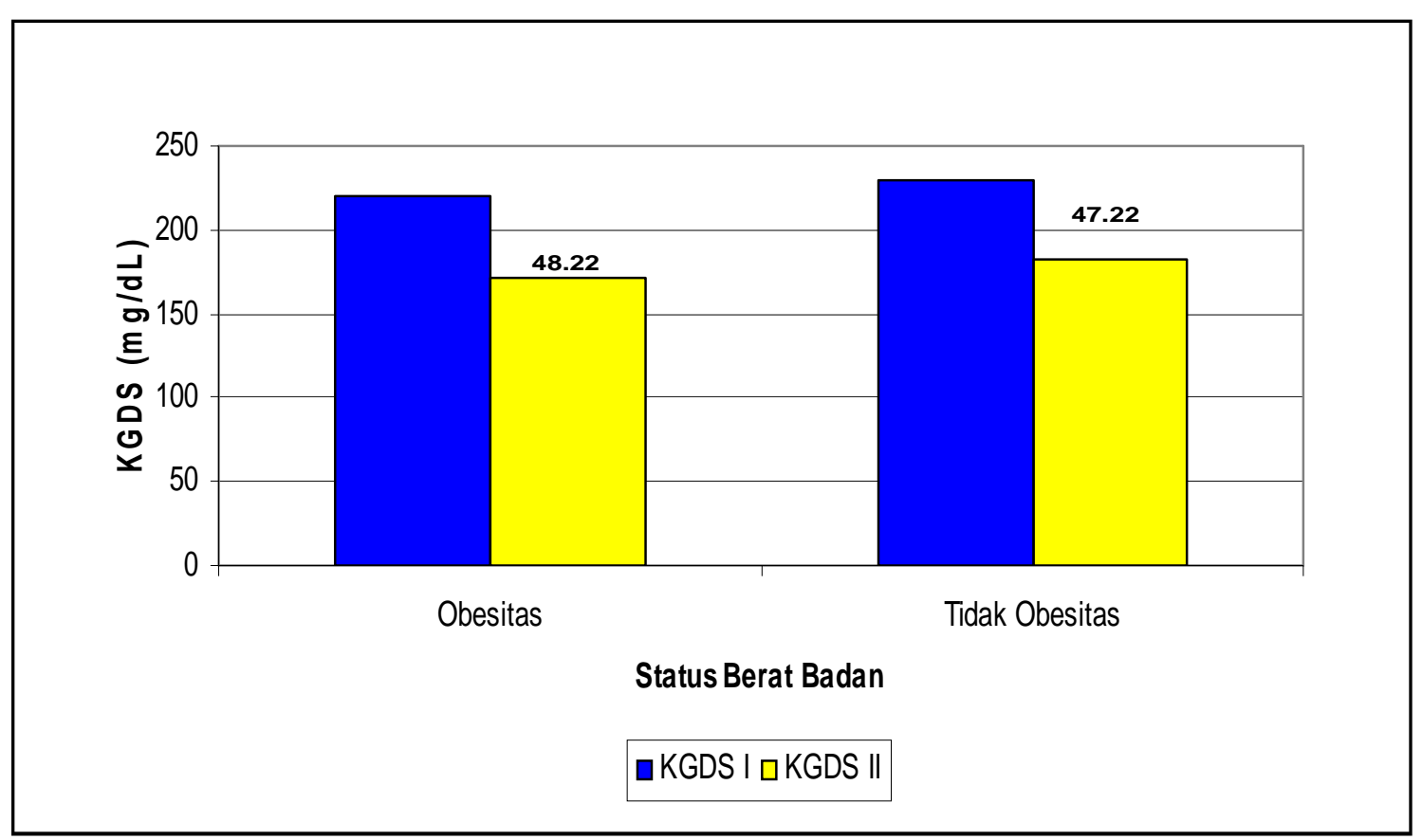


DiNucci, E.M. (2005). Energy healing: A complementary treatment for orthopaedic and other conditions. Orthopaedic Nursing, 24 (4), 259-269.

Elwood, J.M. (2007). Critical appraisal of epidemiological studies and clinical trials. Melbourne: Oxford University Press.

Guyton, A.C. (1996). Human physiology and mechanism of disease. (Alih bahasa oleh Andrianto, P.). Jakarta: EGC.

Ishaq, I.I. (2002). Mengenal usui Reiki I \& II intensif: Sebagai penyembuhan ilahiah. Jakarta: Delapratasa Publishing.

Individual Wellbeing Diagnostic Laboratories. (2008). Individual Wellbeing Diagnostic Laboratories. Diperoleh dari http://www.iwdl.net.

Kozier, B., Erb, G., Blais, K. \& Wilkinson, J.M. (1995). Fundamental of nursing: Concepts, process, and practice. California: Addison Wesley Publishing Company.

McKenzie, E. (2006). Healing reiki. London: Octopus Publising Group Ltd.
Moore, A. (2001). Reiki Healing Touch: Enhancing the Healing Process. Berkshire Medical Journal: 7-9.

National Centers for Complementary and Alternative Medicine. (2007). An introduction reiki. Diperoleh dari http://nccam.nih.gov.

Sjahdeini, S.R. (2005). Hidup sehat dengan reiki dan energi-energi non reiki. Jakarta: Gramedia Widiasarana Indonesia.

Smeltzer, S.C. \& Bare, B.G. (2002). Brunner and Suddarth's texbook of medical-surgical nursing. Philadelphia: Lippincott.

Soegondo, S. (2007). Prinsip pengobatan diabetes, insulin, dan obat hipoglikemik oral, dalam Soegondo, S., et al, Penatalaksanaan diabetes melitus terpadu (hlm. 113-129). Jakarta: FK UI.

Soegoro, R. (2002). Hidup sehat dengan reiki. Jakarta: PT Elex Media Komputindo.

Vitale, A. (2007). An integrative review of reiki touch therapy research. Holistic Nursing Practice, 21 (4), 167-179. 